\title{
SPEECH ACT ANALYSIS OF TEACHER TALK IN EFL CLASSROOM
}

\author{
Aulia Wahyu Santosa ${ }^{1}$, Arik Kurniadi ${ }^{2}$ \\ ${ }^{1,2}$ Universitas Sebelas Maret, Indonesia
}

DOI: 10.23917/humaniora.v20i2.9871

Received: January $11^{\text {st }}, 2020$. Revised: June $10^{\text {th }}, 2020$. Accepted: June $23^{\text {th }}, 2019$

Available Online: August $28^{\text {th }}, 2020$. Published Regulary: August, 2020

\begin{tabular}{|c|c|}
\hline Keywords & Abstract \\
\hline $\begin{array}{l}\text { speech act, } \\
\text { teacher talk, } \\
\text { EFL classroom }\end{array}$ & $\begin{array}{l}\text { The speech act used in EFL classroom may lead to understanding } \\
\text { or misunderstanding due to the distinct cultures between the } \\
\text { origin of language and the users. The objective of the research } \\
\text { were to find out speech act classification mostly used by an EFL } \\
\text { teacher while teaching, the reason of why certain classification }\end{array}$ \\
\hline $\begin{array}{l}\text { Corresponding } \\
\text { Author }\end{array}$ & $\begin{array}{l}\text { was preferred and the implication of the selected speech act clas- } \\
\text { sification toward the teaching and learning process. This re- } \\
\text { search was a case studv research involving an Enolish teacher }\end{array}$ \\
\hline $\begin{array}{l}\text { Aulia Wahyu Santosa } \\
\text { Universitas Sebelas } \\
\text { Maret, } \\
\text { Indonesia }\end{array}$ & $\begin{array}{l}\text { search was a case study research involving an English teacher } \\
\text { teaching an EFL class. The study uses Searle's framework of } \\
\text { speech act classification as the instrument. The findings of the re- } \\
\text { search showed the frequency of each classification found as the }\end{array}$ \\
\hline $\begin{array}{l}\text { Email: } \\
\text { aulia.ws@yahoo.com } \\
\text { Phone: } \\
+6281227225665\end{array}$ & $\begin{array}{l}\text { following: } 57 \% \text { for assertive, } 25 \text { for expressive, } 40 \% \text { for directive, } \\
\text { and 1\% for commissive. Assertive speech acts were used mostly } \\
\text { by the teacher because the teacher gived the students test practice } \\
\text { and discussed it later on. The study concluded that the choice of } \\
\text { speech acts classification determined the teaching approach and } \\
\text { vice versa. }\end{array}$ \\
\hline
\end{tabular}

\section{INTRODUCTION}

The increased learning and teaching of English throughout the world during recent years in both state and commercial educational institutions has produced a new cadre of professionals: teachers of EFL. Some have moved across from teaching English as a mother tongue, others from teaching modern languages; many have been drawn into service for no other reason than that their own spoken English is good, or perhaps because they are native English speakers. Celce-Murcia (2000) pointed out that language use applied in the classroom affect students' process and progress of learning. In the matter of EFL (English as a Foreign Language) teaching in Indonesian context, in which the teachers are not the natives of English, running EFL teaching and learning is troubling in terms of delivering the lesson using English and getting students to understand the instruction mentioned using the language. However, there are problems related to the use of English (as a foreign language) in the classroom.

Basra and Thoyyibah (2017) had done a research involving teacher talk in the classroom. The study entitled A Speech Act Analysis of Teacher Talk in EFL Classroom. They focused on teacher's speaking during the class. The objective of the study is to find out speech act classification mostly used by an EFL teacher while teaching, the reason of why certain classification was preferred and the implication of the selected speech act classification toward the teaching and learning process. They gathered the data by recording the 
teaching process and interviewing the teacher. The result shows that there are four out of five types of speech act classification happened throughout the class. The one that did not happen was Declarative speech act. While the most speech act used by the teacher is directive speech act. When he was interviewed, the reason of why certain classification was preferred and the implication of the selected speech act classification toward the teaching and learning process are because he intended to get students to talk more and to carry out the principle of Communicative Language Teaching as what he believes. Hadhi (2013), in his research, stated that due to consideration of the current situation of EFL teaching, it is recommended that EFL teachers need to introduce speech act theory in the class and deliver relevant knowledge to help students become capable of performing appropriate speech acts in intercultural communication Because not only does speech act theory carries the linguistic rules related to utterances but also leads students to use the language appropriately and effectively (Hadhi, 2013). Those studies above observe speech act in teacher talk when the teacher discuss about a text and focused on reading. Meanwhile this study focused more on the speech act that happen when the teacher hold practice and discussion in the class.

\section{Teacher talk}

For foreign language learners, classroom is the main place where they are frequently exposed to the target language. The kind of language used by the teacher for instruction in the classroom is known as teacher talk. For this term, Longman Dictionary of Language Teaching and Applied Linguistics defines it as "that variety of language sometimes used by teachers when they are in the process of teaching. In trying to communicate with learners, teachers often simplify their speech, giving it many of the characteristics of foreigner talk and other simplified styles of speech addressed to language learners" (Richards, 1992:471)

Having studied the SLA for many years, Rod Ellis (1985) has formulated his own view about teacher talk: "Teacher talk is the special language that teachers use when addressing L2learners in the classroom. There is systematic simplification of the formal properties of the teacher's language... studies of teacher talk can be divided into those that investigate the type of language that teachers use in language classrooms and those that investigate in the type of language they use in subject lessons." He also commented that the language that teachers address to L2 learner is treated as a register, with its own specific formal and linguistics properties.

\section{Pragmatic}

Pragmatics is defined as a small part of linguistics and semiotics that studies the contribution of a context toward meaning. Akinwotu in Basra (2017) explains that pragmatic is a study of language in use. Furthermore, Murcia (2000) stated pragmatics is "...the study of relationship holding between linguistic forms and the human beings who use these forms".

The wider definition comes from Yule (1996). He states that pragmatics is the study of speaker meaning. Pragmatic is the study of the contextual meaning, the second definition. The third definition, pragmatics is the study of how more gets communicated than said. The last definition is that pragmatics is the study of expression of relative distance. Yule also says that to understand pragmatics briefly, there is a need to make a relationship with other areas of linguistics. Semantics and syntax can be related to this study. By referring to the explanations that have been mentioned, it can be said that pragmatics is a study about the relationship between language, meaning and context or situation.

\section{Speech act}

Speech acts are those acts of making statement or question, giving commands or order, refusing, complimenting, apologizing, and etc. Yule (1996) acknowledged that by 
performing speech acts, people do not merely say something using the language out of the blue. Instead, they have intention and force behind the utterances they utter and those utterances may affect the behavior of the hearer. According to Austin (1975), speech act is a theory of language where the point of communication is on the meaning which is more important rather than the language that being used. Mey (1993) states "the first thing one should notice is that speech acts are actions happening in the world. Meanwhile, Fauziati (2016) explained that the basis of speech act theory is on the real meaning that can be conclude from the sayer by saying certain utterance, rather than the language used to convey the utterance.

\section{Speech act classification}

A number of different scholars revealed different speech acts classifications which actually were originated from Austin's. Oluremi (2016) pointed out that Austin's speech acts classifications include verdictives, exercitives, commissives, behabitives, and expositives. However, a popular American Philosopher, John R. Searle, extended the ideas, making his taxonomy a reference or framework of speech act classification used by many researchers conducting research on speech act classification. Searle (1999) categorized five different types of illocutionary acts; assertive force, directive force, commissive force, expressive force, and declarative force. Yule (1996) represented a table of the five speech acts classification based on the theory of Searle.

Table 1. Searle's Speech act classification

\begin{tabular}{clc}
\hline Speech act type & Direction of fit & S = Speaker; X = Situation \\
\hline Declarative & Words change the world & S causes X \\
Assertive & Make words fit the world & S believe X \\
Expressive & Make words fit the world & S feels X \\
Directive & Make the world fit words & S wants X \\
Commisive & Make the world fit words & S intends X \\
\hline
\end{tabular}

From the theories and studies above, the researcher tries to focus on speech act uttered by the teacher during the class. The objective of this study is to analyze the speech act classification mostly used by an EFL teacher while teaching, the reason of why certain classification was preferred and the implication of the selected speech act classification toward the teaching and learning process.

\section{METHOD}

\section{Research design}

This research belongs to case study. The aim of the study is to investigate classroom speech act performed by an English instructor in an English course. Yin (2018) explained that case study research is most likely to be appropriate for "how" and "why" questions. This study also followed the advice of Cresswell (2012) who suggested that qualitative case study method is required to be used in order to gain exploration and understanding of certain phenomenon in the field. Hence, case study is suit for this research since the main purpose of the research is to reveal how speech act is performed by the teacher during the teaching and learning process.

\section{Participant}

This research involved an English instructor. He is 24 years old. He has a remarkable experience related to English teaching. The instructor was chosen for some reasons. He has 557 score of TOEFL and has been teaching English for about three years. Meanwhile, the class from an English course was chosen because it was mainly focused on university entrance test which the writers hypothesize would have different result with the previous study. 


\section{Material}

There some types of data that had been collected. First, a video recording of a teaching and learning process in one meeting which lasts for 90 minutes. Second, a short interview with the instructor. Third, some pictures that can be used as an authentic document from the learning process.

\section{Procedure}

The data collecting procedure started with an observation. The video recording was taken from the classroom where the teaching and learning process taken place. Second, the instructor was interviewed to get more data related to the topic of the research which is speech act. After the data were collected, the video recording was transcribed to visualize the utterance produced by the instructor. The writers use framework by Searle (1976), then, applied to classify what utterance belonged to each speech act classifications. The classifications defined by Searle were assertive, directives, commisives, expressives, and declaratives.

\section{RESULT}

Classification of the speech act used by the writers is from Searle that classifies speech act into five types; declarative, assertive, expressive, directive, and comisssive. The writers found 227 speech act uttered by the teacher in the whole lesson. Assertives is one of speech act types that is used the most by the teacher during the lesson by showing $57 \%$ of talk using assertives. Meanwhile, declarative type of speech act shows completely opposite result. The teacher does not use any declarative sentence in the classroom.

\section{Declarative $(0 \%)$}

It is found that only four out of five types of speech act used by teacher. He did not utter any declarative speech act in the class that changes the world of the hearer via utterances uttered by a speaker (Yule, 1996). It means that speech act uttered by a speaker changes the world or situation. The speaker needs to have a special institutional role to change the world of the hearer. The changing world of the hearer means that the situation which is changed from him/her/them caused by a speaker is not easy to be avoided or broken or left.

\section{Assertive (57\%)}

Assertive speech acts dominate the utterance said by the teacher in the teaching process. Assertive is a type of illocutionary point stated what one's belief to be the case or not. Speakers achieve the assertive point when they represent how things are in the world (ThoughtCo, 2019). Here are the list of assertive speech act that mostly uttered by the teacher during the lesson:

Table 2. Finding of assertives speech act uttered by the teacher

\section{Utterances}

"It is parallel, it needs to be in line."

"D because there is will there."

"Will is always followed by verb $0 . "$

"A, hang on means wait a minute."

\section{Expressive (2\%)}

Expressives are those kinds of speech acts that state what the speaker feels. They express psychological states and can be statements of pleasure, pain, likes, dislikes, joy, or sorrow. Beijer (Beijer, 2003) states that the term emotional/expressive utterances refers to any utterance in which the speaker in question is emotionally involved, and in which 
this involvement is linguistically expressed by means of intonation or by the use of performative expressions. 4 utterances indicated as expressive speech act are found in the data. Qadir and Riloff (2011) categorized utterances with expressive essence by signaling clues like thanking, apologizing, congratulating, condoling, deploring, appreciating, and welcoming. Among those 4 utterances, most expressive speech act uttered are listed below:

a. Thank you (name of student).

b. I am sorry.

The utterance like "thank you" is always mentioned by the teacher after receiving things from the students or whenever her students try to remind her about something. "I'm sorry" is uttered when the teacher makes mistakes such as forgetting students' names or after making jokes that she thinks might hurt her students. In the interview, she admitted that her reason of doing so is basically a habit because people are supposed to say "thank you" when somebody gives them something, say "sorry" if they think they might hurt somebody else's feeling. The other reason is that the teacher wants to grow those basic habits in her students by being a good role model of a social human being. Therefore, the students will do the same when they interact inside or outside of the classroom.

\section{Directive (40\%)}

Among those 227 utterances, 92 or $40 \%$ of them have directive speech acts word clues. Qadir and Riloff (2011) listed clues of directive speech act word. Utterances containing the force or intention to ask, order, command, request, beg, plead, pray, entreat, invite, permit, advise, dare, defy, and challenge, are categorized into directives. Mostly, the teacher used directives with the intention is to ask the students about something, and to command and request the students to do something. These are the words that are said by the teacher:

Table 3. Finding of directives speech act uttered by the teacher

\begin{tabular}{lc}
\multicolumn{1}{c}{ Utterance } & Directive Categories \\
\hline Let's discuss together. & Order \\
Number 121 please read start from Deta & Command \\
122 miss Eka (asking the student to read the question) & Order \\
\hline Is there any other answer? & Asking \\
\hline Let's move on to error questions number 151. & Order \\
\hline Which one is incorrect? & Asking \\
\hline What should it be? & Asking \\
\hline Is there any question? & Asking \\
\hline
\end{tabular}

\section{Commissive (1\%)}

Commissive speech acts are the least mentioned by the teacher while teaching. Commissives are those kinds of speech acts that speakers use to commit themselves to some future actions. They express what the speaker intends. They are promises, threats, refusals, pledges, and can be performed by the speaker alone, or by the speaker as a member of a group. The teacher only mentioned 2 utterances with commissive essence, which means the percentage is only $1 \%$ out of $100 \%$. These are the utterances categorized as commissive speech act:

a. Today we are going to have another practice.

Okay guys, we are going to have a break for 15 minutes.

\section{DISCUSSION}

The data of this study was gathered by conducting interview and field observation. In the interview session, the teacher said that she does not really think of the utterance 
that she used to explain the material. What come to her mind was that the students would understand her explanation. Because the agenda of that meeting was practice and discuss questions, so the utterance that was used the most is assertives. She stated, "I asked my students first about the possible answer to a question, but then I have to give them the correct answer and explain it". As explained by Searle (1979), the point or purpose of assertive is to commit to the truth of the expressed proposition, it can be concluding or deducing

It can be concluded that, there is one main reason why the teacher unconsciously use assertives speech acts which is met with the principle of CLT (Communicative Language Teaching) Approach. Richards (2006) defined CLT as an approach which highly values communicative competence rather than grammatical competence. Because the teacher had to elaborate each and every questions directly to the students so it is understandable if she did not pay attention to each sentences she said. The point that is stated by the teacher was also met with theory of communicative competence. According to Celce-Murcia (1995), one of components of communicative competence is actional competence, which closely related to speech act.

The implication of the selected speech act classification toward the teaching and learning process was that, the teacher could deliver the material effectively to the students by asking them first, rather than giving out the correct answer directly. Test discussion activity is rarely used by others' researcher to examine its speech act. That is why the result of this study is contrast with Arani (2012) that shows directive speech act as the preferred types to use in EFL classroom. She examined a teacher when he explain a material to the student, rather than test discussion activity.

\section{CONCLUSION}

The use of appropriate speech act classification while teaching is based on the teaching approach the teacher adopts. This study aims at investigating speech acts classification of teacher talk in EFL classrooms, the reason of the teacher uses certain speech acts, and the implication that can be drawn from the finding. Based on the findings and discussion, four classifications of speech acts are found from the data (teacher talk). The total of the utterances uttered by the teacher in one meeting of teaching and learning is 227 utterances. Four classifications have different portions, with assertive speech acts as the dominant one, taking over $57 \%$ of the utterances. The second dominant classification is directive speech act for $40 \%$. The expressive and commissive speech acts have small portions, namely $2 \%$ and $1 \%$, respectively. The teacher argued that her reasons of using more assertive speech acts are to make students understand about the material. Because the material that is taught that day is practice and discussion, so the students need to have correct understanding of each of the materials. The recommendation is addressed for English teachers, especially in Indonesian context. Teaching Indonesian students a language which is foreign for them is not an easy task. Then, to expose them more to English, the classroom language instruction which is better to be used is English. However, teaching with foreign language instruction can cause trouble and misunderstanding between teacher and students. English teachers should realize soon their belief in teaching English.

\section{REFERENCES}

Arani, S. S. (2012). A study of directive speech acts used by Iranian nursery school children: The impact of context on children's linguistic choices. International Journal of Applied Linguistics \& English Literature, 1(5), 163175.

Austin, J. L. (1975). How to Do Things with Words. In Jaworski, Adam and Nikolas Coupland (Eds.), The Discourse Reader (P 55-65). London, England: Routledge.

Basra, S. M., \& Thoyyibah, L. (2017). A speech act analysis of teacher talk in an EFL classroom. International Journal of Education, 10(1), 73-81. doi: http://dx.doi.org/10.17509/ije.v10i1.6848 
Beijer, F. (2003). The pragmatics of exclamations and other expressive emotional utterances. Stockholm, Sweden: University of Yarnn.

Broughton, G., Brumfit, C. \& Flavell, R. (2003). Teaching English as a Foreign Language. London, England: Routledge

Celce-Murcia M, Dörnyei Z, Thurrell S (1995) A pedagogical framework for communicative competence: A Pedagogically motivated model with content specifications. Issues in Applied Linguistics 6(2): 5-35

Celce-Murcia, M. \& Olshtain E. (2000). Discourse and context in language teaching: a guide for language teachers. Cambridge, England: Cambridge University Press.

Creswell, John W. (2002). Educational research: planning, conducting, and evaluating quantitative and qualitative research. Boston, United States: Pearson Education, Inc.

Ellis, R. (1985). Understanding Second Language Acquisition. Shanghai, People's Republic of China: Shanghai Foreign Language Education Press.

Fauziati, E. (2016). Applied Linguistics: Principles of Foreign Language Teaching, Learning, and Researching. Surakarta, Indonesia: Era Pustaka Utama.

Hadhi, P. (2013), Speech Act in English Language Teaching, Faculty of Humanities, Depok.

Harmer, J. (2007). How to teach English. Cambridge, England: Pearson Education Limited.

Mey, L. Jacob. (1993). Pragmatics: An Introduction. Massachussets: Blackwell Publisher Inc.

Oluremi, Ajewole-Orimogunje C. (2016). Speech acts and Welfarist Ideology in Governor Aregbesola's May 1, 2013 Address. International Journal of English Language and Linguistics Research, 4(4), 23-32.

Qadir, A. ,\& Riloff, E. (2011). Classifying sentences as speech acts in message board posts. In (2011) Conference on Empirical Methods is Natural Language Processing (pp 748-758). Retrieved from https://www.researchgate.net/publication/221012916_Classifying_Sentences_as_Speech_Acts_in_Message_Board_Posts

Richards, J. C. (1992). Longman Dictionary of Language teaching \& Applied linguistics. London, England: Longman

Searle, J. R. (1976). A Classification of Illocutionary Acts. Language in Society, 5(1), 123.

Searle, J. R. (1999). Mind, language and society: Philosophy in the real world. Phoenix: Guernsey Press Co.

ThoughtCo. (2019). Speech Act Theory. Retreieved from https://www.thoughtco.com/speech-act-theory-1691986

Yin, R. K. (2018). Case Study Research \& applications: Design and methods (Sixth edition). Los Angeles: Sage, Thousand Oaks.

Yule, G. (1996). Pragmatics. Oxford, England: Oxford University Press. 